\title{
Potensi Ekosistem Terumbu Karang untuk Pengembangan Ekowisata di Pulau Sintok Taman Nasional Karimunjawa
}

\author{
Maulana Cahya Widhiatmoko*, Hadi Endrawati, Nur Taufiq-SPJ \\ Departemen IImu Kelautan, Fakultas Perikanan dan IImu Kelautan, Universitas Diponegoro \\ Jl. Prof.H.Soedarto S.H, Tembalang,Semarang, Jawa Tengah 50275 Indonesia \\ ${ }^{*}$ Corresponding author, e-mail: maulana.mc@gmail.com
}

\begin{abstract}
ABSTRAK: Ekosistem terumbu karang merupakan habitat berbagai biota laut bernilai ekonomis tinggi. Ekowisata merupakan perjalanan wisata ke wilayah alami maupun buatan dengan tujuan konservasi untuk menjamin kelestarian alam dan sosial- budaya. Tujuan penelitian ini untuk mengetahui potensi biofisik terumbu karang untuk pengembangan ekowisata serta mengetahui analisis strategi pengembangan ekowisata terumbu karang di Pulau Sintok Karimunjawa. Pengamatan biofisik ekosistem terumbu karang dilakukan menggunakan metode LIT atau Line Transect. Data yang didapat dianalisis menggunakan indeks kesesuaian ekowisata selam dan analisis SWOT. Hasil menunjukkan bahwa tutupan karang hidup di Pulau Sintok pada keempat titik pengambilan berkisar antara 30-82\%. Berdasarkan analisis kesesuaian ekowisata, kawasan perairan Pulau Sintok memiliki nilai IKW (Indeks Kesesuaian Wisata) $>50-83 \%$ dimana nilai $50 \%-<80 \%$ termasuk kedalam kelas (S2) atau suitable dan nilai IKW $83 \%$ termasuk ke dalam kategori (S1) atau sangat sesuai untuk dijadikan sebagai ekowisata terumbu karang kategori selam. Analisis strategi pengelolaan kawasan pengembangan ekowisata di perairan Pulau Sintok adalah dengan : pengelolaan kawasan terumbu karang sebagai ekowisata secara optimal, perlunya upaya pencegahan kerusakan ekosistem terumbu karang untuk dijadikan kawasan ekowisata, pengembangan sistem informasi serta meningkatkan sarana prasarana pengelolaan ekowisata, dan Penegakkan hukum dan peraturan perundang-undangan demi penerapan pengelolaan terumbu karang secara lestari.
\end{abstract}

Kata Kunci : Terumbu Karang, Ekoturisme, Karimunjawa

\section{Potensial of Coral Reef Ecosystem for Development of Ecoturism in Sintok Island, Karimunjawa National Park}

ABSTRACT: The coral reef ecosystems are habitats for various marine biota, which have a high economic value. Coral reef ecosystems provide merits to support the marine tourism industry for foreign exchange earnings. They also provide significant employment and business opportunities. Coral reef ecosystems which have a good condition can be developed into coral reef ecotourism. Ecotourism is a tour to natural and artificial areas with the purpose of conservation to ensure the natural and socio-cultural sustainability. The purpose of this research is to find out the biophysical potential of the coral reefs for the development of ecotourism, and to perceive the analysis of the development strategy of coral reef ecotourism in Sintok Island, Karimunjawa. The biophysical observation of coral reef ecosystems is conducted with LIT or Line Transect method. The data obtained is analyzed using ecotourism suitability index and SWOT analysis. The result of this research shows that living coral cover on Sintok Island at the four taking points ranged from 30-82\%. According to the analysis of ecotourism suitability, Sintok Island waters area has IKW value (Tourism Suitability Index) $>50-83 \%$. The value of $50 \%-<80 \%$ belongs to the class (S2) or suitable, and the IKW value of $83 \%$ belongs to the category (S1) or very suitable to be used as coral reef ecotourism category. The analysis of the management strategy of ecotourism development area in Sintok Island waters are as follows: (1) The optimal management of coral reef area as ecotourism, (2) The prevention of coral reef ecosystems from damage, (3) The development of information system, as well as the 
enhancement of ecotourism management infrastructure, and (4) The enforcement of laws and regulations for the sake of coral reefs' sustainable management.

Keywords: Coral Reef; Ecotourism; Karimunjawa

\section{PENDAHULUAN}

Terumbu karang merupakan ekosistem dinamis dengan kekayaan biodiversitas serta produktivitas tinggi, karena itu terumbu karang mempunyai peran yang signifikan. Secara ekologis, terumbu karang merupakan tempat organisme hewan maupun tumbuhan mencari makan dan berlindung. Menurut Suharsono (2008), Indonesia memiliki jenis-jenis karang yang beragam, ditemukan 590 spesies yang termasuk kedalam 80 genus karang di Indonesia. Menurut hasil penelitian Pusat Pengembangan Oseanologi (P2O) LIPI yang dilakukan pada tahun 2000, kondisi terumbu karang Indonesia 41,78\% dalam keadaan rusak, 28,30\% dalam keadaan sedang, 23,72\% dalam keadaan baik, dan $6,20 \%$ dalam keadaan sangat. Ekosistem terumbu karang menyediakan jasa-jasa menunjang industri wisata bahari bagi perolehan devisa negara dan menyediakan lapangan pekerjaan dan lapangan usaha yang signifikan (Puspitasari et al., 2016).

Potensi wisata bahari khususnya ekowisata terumbu karang di wilayah pesisir dilakukan sebagai upaya untuk menguatkan wisata bahari yang sudah ada. Selain itu perlu mengetahui daya dukung wilayah secara fisik, lingkungan dan kewilayahan. Hal ini diperlukan sebagai salah satu masukan dalam pemanfaatan sumber daya pesisir yang berkelanjutan. Dalam pengelolaannya diperlukan keterpaduan antar berbagai pihak, yang tergabung dalam satu koordinasi yang mengarahkan berbagai kegiatan yang ada di wilayah pesisir tersebut. Hal ini dimaksudkan sebagai suatu upaya secara terprogram untuk mencapai tujuan yang dapat mendukung antara berbagai kepentingan, agar terpelihara lingkungan dan tercapainya pembangunan ekonomi yang memadai.

Definisi pulau menurut Jaelani (2012) adalah daratan yang terbentuk secara alami, dikelilingi oleh air dan selalu berada di atas permukaan air pada saat pasang tertinggi. Sementara pengertian pulau-pulau kecil menurut Undang- Undang No. 27 Tahun 2007 tentang Pengelolaan Wilayah Pesisir dan Pulau- Pulau Kecil adalah pulau dengan luas lebih kecil atau sama dengan $2.000 \mathrm{~km}$ persegi beserta kesatuan ekosistemnya. Taman Nasional Karimunjawa merupakan salah satu taman nasional yang didalamnya terdapat pulau-pulau kecil. Salah satu pulau kesil di kawasan Taman Nasional Karimunjawa adalah Pulau Sintok. Pulau Sintok merupakan pulau kecil yang memiliki potensi ekosistem pesisir yang melimpah, salah satunya adalah Ekosistem Terumbu Karang.

Penelitian ini bertujuan untuk mengetahui kondisi biofisik ekosistem terumbu karang sebagai pengembangan ekowisata bahari serta untuk mengetahui strategi pengembangan ekowisata di Pulau Sintok Taman Nasional Karimunjawa. Penelitian ini diharapkan dapat memberikan informasi dan masukan untuk pembuatan perencanaan pengembangan wilayah tersebut khususnya untuk pengembangan wisata bahari. Selanjutnya data yang diperoleh dapat digunakan sebagai dasar pengelolaan ekosistem terumbu karang yang meliputi eksplorasi secara lestari, perlindungan dan pencegahan terhadap polusi dan degradasi yang disebabkan aktifitas manusia.

\section{MATERI DAN METODE}

Materi yang dipergunakan dalam penelitian ini adalah kondisi biofisik ekosistem terumbu karang dan arahan strategi pengembangan ekowisata bahari kategori selam di Pulau Sintok Taman Nasional Karimunjawa. Lokasi penelitian ditunjukkan pada Gambar 1. Penelitian yang dilakukan terbagi menjadi dua bagian yaitu penelitian yang dilakukan di lapangan meliputi pendataan kerapatan terumbu karang yang meliputi persen cover karang hidup, keseragaman, keanekaragaman, dan dominansi, selain itu pengukuran parameter kualitas perairan juga dilakukan dilapangan secara langsung. Pendataan karang berdasarkan dengan bentuk pertumbuhan (life form). Penelitian kedua adalah menganalisis data yang telah didapat. Pengambilan data kondisi biofisik ekosistem terumbu karang menggunakan metode Transek Garis atau Line Intercept Transect (LIT). 


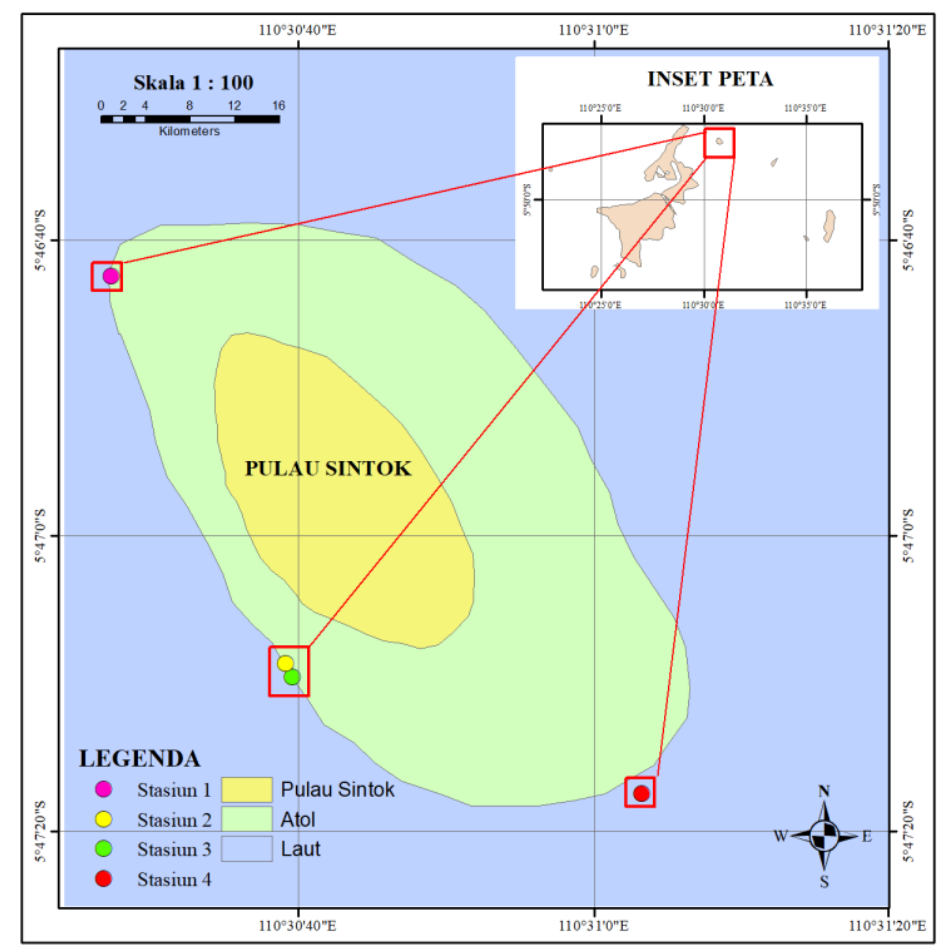

Gambar 1. Lokasi Penelitian di Pulau Sintok Taman Nasional Karimunjawa

\section{Pengukuran Kualitas Perairan}

Pengukuran parameter perairan dilakukan secara langsung dilapangan. Pengukuran parameter perairan meliputi suhu menggunakan thermometer, kecerahan perairan menggunakan secchi disc, kecepatan arus menggunakan bola duga, salinitas dengan hand refraktometer, dan derajat keasaman menggunakan $\mathrm{pH}$ meter. Kecerahan perairan adalah suatu kondisi yang menunjukkan kemampuuan cahaya untuk menembus lapisan air pada kedalaman tertentu. Pada perairan alami kecerahan sangat penting karena erat kaitannya dengan dengan aktivitas fotosintesis hewan karang (Effendi, 2003).

\section{Pengambilan Data Terumbu Karang}

Metode yang digunakan pada pengambilan data biofisik terumbu karang yaitu LIT (Line Intercept Transect). Metode LIT biasa juga dikenal dengan nama metode transek garis (Indonesia). Metode Transek garis (LIT) merupakan metode dasar untuk menggambarkan struktur komunitas karang berdasarkan bentuk pertumbuhan (life form) (English et al., 1997). Metode LIT digunakan dengan cara membentangkan transek garis (roll meter) sepanjang 100 meter yang dipasang sejajar dengan garis pantai seperti pada Gambar 2. Pengambilan data dilakukan pada 4 stasiun yang telah di tentukan, dimana setiap stasiun dilakukan pengulangan 2 kali yaitu di kedalaman 5 dan 10 meter. Data yang diambil setiap centimeter meliputi bentuk pertumbuhan karang, biota yang berasosiasi, dan substrat. Selain itu data yang diambil yaitu lokasi pengambilan data menggunakan GPS. Identifikasi jenis life form meliputi tipe pertumbuhan yang terjadi pada ekosistem terumbu karang pada lokasi penelitian. Jenis atau tipe pertumbuhan karang yang ditemui pada tiap line transek dicatat.

\section{Prosentase Tutupan Terumbu Karang}

Dari hasil prosentase tutupan lifeform yang diperoleh disajikan setiap stasiun dan dianalisis secara deskriptif dengan tabel atau grafik sehingga dapat ditentukan kondisi terumbu karang di daerah tersebut (Gomes dan Yap, 1988) dengan melihat kriteria tutupan karang hidup (Tabel 1). 


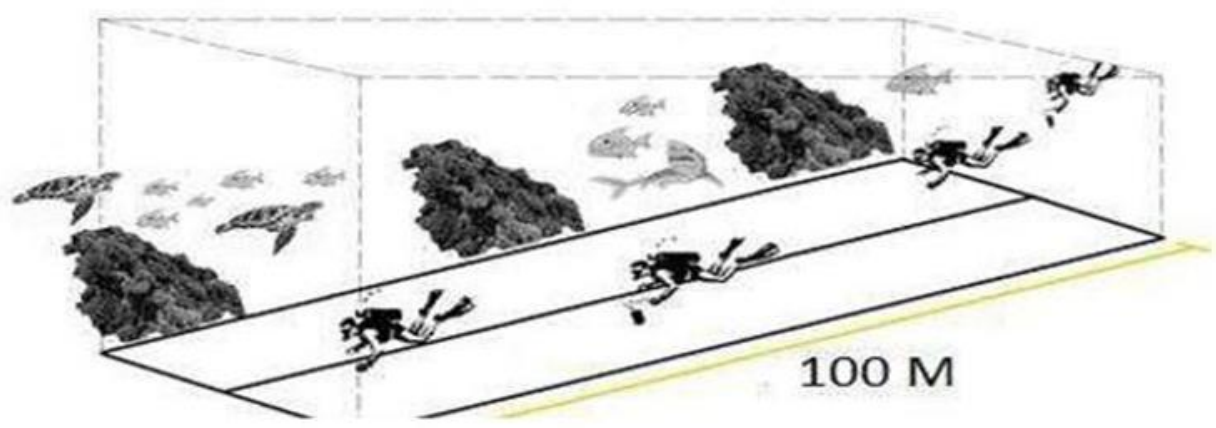

Gambar 2. Pengukuran Ekosistem Terumbu Karang dengan Metode LIT (Sumber. UAS et al., 2017).

Tabel 1. Kriteria Tutupan Karang Hidup di Pulau Sintok Taman Nasional Karimunjawa

\begin{tabular}{ccc}
\hline Kategori & Tutupan Karang Hidup & Kriteria \\
\hline $\mathbf{1}$ & $75-100 \%$ & Sangat Baik \\
$\mathbf{2}$ & $50-74,9 \%$ & Baik \\
$\mathbf{3}$ & $25-49,9 \%$ & Sedang \\
$\mathbf{4}$ & $0-24,9 \%$ & Rusak \\
\hline
\end{tabular}

\section{Indeks Kesesuaian Ekowisata}

Analisis kesesuaian didasarkan pada potensi sumber daya yang ada dan parameter kesesuaian untuk setiap kegiatan wisata. Kesesuaian wisata bahari, sebagai ketetapan atau kecocokan penggunaan sumberdaya kelautan terhadap suatu kegiatan dikarenakan setiap kegiatan wisata bahari mempunyai persyaratan sumberdaya lingkungan yang sesuai dengan objek wisata yang akan dikembangkan. Analisis kesesuaian lokasi wisata bahari kategori wisata selam menggunakan pendekatan kualitas kondisi biofisik lokasi, antara lain : luas tutupan komunitas karang, jenis life-form, jumlah jenis ikan, kedalaman terumbu karang, kecerahan perairan dan kecepatan arus. Parameter-parameter tersebut diberi nilai berdasarkan matrik kesesuaian wisata selam seperti yang tertera pada Tabel 2.

Tabel 2. Matriks Kesesuaian Ekowisata Selam (Yulianda, 2007)

\begin{tabular}{|c|c|c|c|c|c|}
\hline No. & Parameter & Bobot & $\begin{array}{c}\text { Standar } \\
\text { Parameter }\end{array}$ & Skor & $\begin{array}{c}\mathrm{N} \\
\text { (Bobot x Skor) }\end{array}$ \\
\hline 1 & Kecerahan Perairan (\%) & 5 & $\begin{array}{c}>80 \\
50-80 \\
20-80 \\
<20\end{array}$ & $\begin{array}{l}3 \\
2 \\
1 \\
0\end{array}$ & \\
\hline 2 & $\begin{array}{l}\text { Tutupan komunitas karang } \\
(\%)\end{array}$ & 5 & $\begin{array}{c}>75 \\
50-75 \\
25-50 \\
<25\end{array}$ & $\begin{array}{l}3 \\
2 \\
1 \\
0\end{array}$ & \\
\hline 3 & $\begin{array}{l}\text { Jumlah jenis life-form } \\
\text { karang }\end{array}$ & 3 & $\begin{array}{c}>12 \\
7-12 \\
4-7 \\
<4\end{array}$ & $\begin{array}{l}3 \\
2 \\
1 \\
0\end{array}$ & \\
\hline 4 & Jumlah jenis ikan karang & 3 & $\begin{array}{c}>\quad 100 \\
50-100 \\
20-50 \\
<20\end{array}$ & $\begin{array}{l}3 \\
2 \\
1 \\
0\end{array}$ & \\
\hline
\end{tabular}




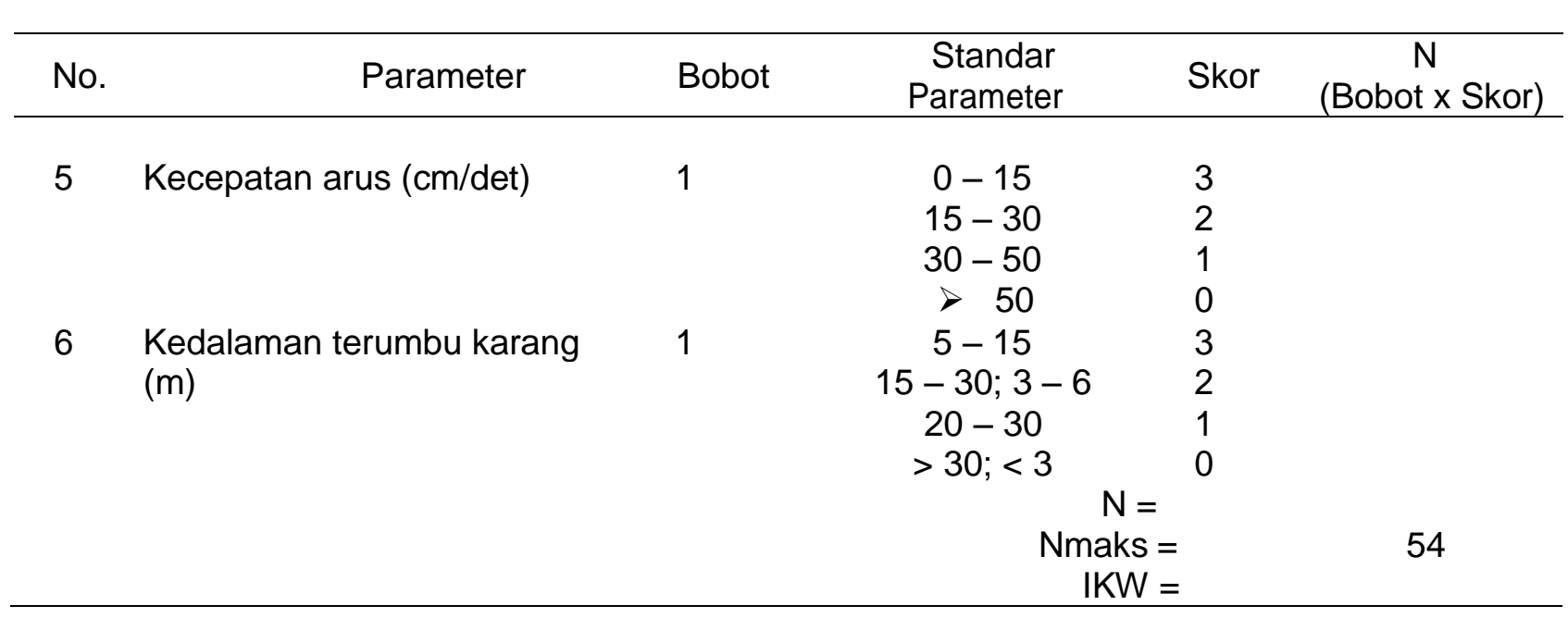

Menurut Yulianda (2007), Untuk menentukan indeks kesesuaian pemanfaatan wisata selam diformulasikan sebagai berikut :

$$
I K W=\sum \frac{N i}{N \text { maks }} \times 100 \%
$$

Keterangan : IKW = Indeks kesesuaian wisata; $\mathrm{Ni}=$ Nilai parameter ke-i (bobot $\mathrm{x}$ skor); Nmaks = Nilai maksimum dari suatu kategori wisata

Ketentuan untuk kelas kesesuaian aktivitas wisata selam (modifikasi dari Yulianda 2007) adalah sebagai berikut: S1 = Sangat sesuai, dengan IKW $83-100 \%$; S2 = Sesuai, dengan IKW $50-<83 \%$; $\mathrm{N}=$ Tidak sesuai, dengan IKW $<50 \%$

Berdasarkan parameter tersebut disusun matrik kesesuaian. Kelas-kelas kesesuaian pada matriks tersebut menggambarkan tingkat kecocokan dari suatu bidang untuk pemanfaatan tertentu. Dalam penelitian ini, kelas kesesuaian dibagi dalam 3 kelas yaitu (1) Kelas S1: Sangat sesuai (highly suitable), yaitu kawasan ekosistem terumbu karang tidak mempunyai pembatas yang berat untuk dikembangkan sebagai kawasan wisata bahari (diving) secara lestari, atau hanya mempunyai faktor pembatas yang kurang berarti dan tidak terpengaruh secara nyata terhadap kondisi kawasan tersebut, serta tidak menambah masukan (input) untuk dikembangkan sebagai objek wisata bahari. (2) Kelas S2: Sesuai (suitable), yaitu kawasan ekosistem terumbu karang yang mempunyai pembatas agak berat untuk pemanfaatan sebagai kawasan wisata bahari secara lestari. Faktor pembatas tersebut akan mengurangi pemanfaatan kawasan tersebut, sehingga diperlukan upaya tindakan tertentu dalam membatasi pemanfaatan dan mengupayakan konservasi dan rehabilitasi. (3) Kelas N: Tidak sesuai (not suitable), yaitu kawasan ekosistem terumbu karang yang mengalami tingkat kerusakan yang tinggi, sehingga tidak memungkinkan untuk dikembangkan sebagai kawasan wisata bahari. Untuk itu sangat disarankan untuk dilakukan perbaikan dengan teknologi tinggi dengan tambahan biaya dan perlu waktu yang lama untuk memulihkannya melalui konservasi dan rehabilitasi kawasan tersebut.

Analisis SWOT (Strength, Weakness, Opportunity, Threat) adalah identifikasi berbagai faktor secara sistematis untuk merumuskan strategi (Rangkuti, 1997). Analisis strategi pengelolaan merupakan analisis untuk memperoleh strategi yang akan dilakukan dalam mengelola kawasan konservasi dan kawasan wisata bahari. Atas dasar hasil suatu analisis yang didapat selanjutnya dilakukan analisis rencana pengelolaan kawasan sumberdaya terumbu karang di perairan Pulau Biawak dan sekitarnya sebagai kawasan wisata selam. Analisis dilakukan dengan menerapkan kriteria kesesuaian data kuantitatif dan deskripsi keadaan.

\section{HASIL DAN PEMBAHASAN}

Hasil pengambilan data prosentase tutupan karang hidup yang telah di dapat stasiun 4 (timur) Pulau Sintok kedalaman 10 meter sebesar $82 \%$ dimana prosentase tersebut menurut ( Keputusan 
Menteri Lingkungan Hidup,2004), termasuk dalam kategori baik sekali. Prosentase penutupan karang terendah berada pada sisi stasiun 2 (barat daya) Pulau Sintok kedalaman 10 meter sebesar $30 \%$ dimana besar prosentase tersebut menunjukkan kondisi terumbu karang di titik pengambilan data tersebut dalam kategori sedang karena menurut (Keputusan Menteri Lingkungan Hidup, 2004), terumbu karang termasuk dalam kategori sedang apabila prosentase penutupan karang $25-49,9 \%$. Prosentase penutupan karang pada kedalaman 5 meter dapat dilihat pada (Gambar 3). Diagram prosentase pada gambar 1 menunjukkan perbandingan prosentase karang hidup, substrat dan komponen lainnya yang telah didata di setiap sisi perairan Pulau Sintok Karimunjawa. Dari gambar 5 terlihat bahwa Pulau Sintok pada kedalaman 5 meter masih didominasi oleh karang hidup. Prosentase penutupan karang tertinggi pada stasiun 3 (tenggara) Pulau Sintok dengan nilai prosentase penutupan karang sebesar $80 \%$. Pada stasiun 4 (timur) kedalaman 5 meter didominasi karang hidup dengan prosentase $77 \%$ dan substrat yang didapat pada stasiun 4 didominasi oleh pasir dengan prosentase 19\%. Pada stasiun 1 (Barat) Pulau sintok memiliki tutupan karang hidup sebesar $68 \%$, sedangkan pada sisi stasiun 2 (baratdaya) Pulau Sintok memiliki prosentase karang hidup sebesar $61 \%$.

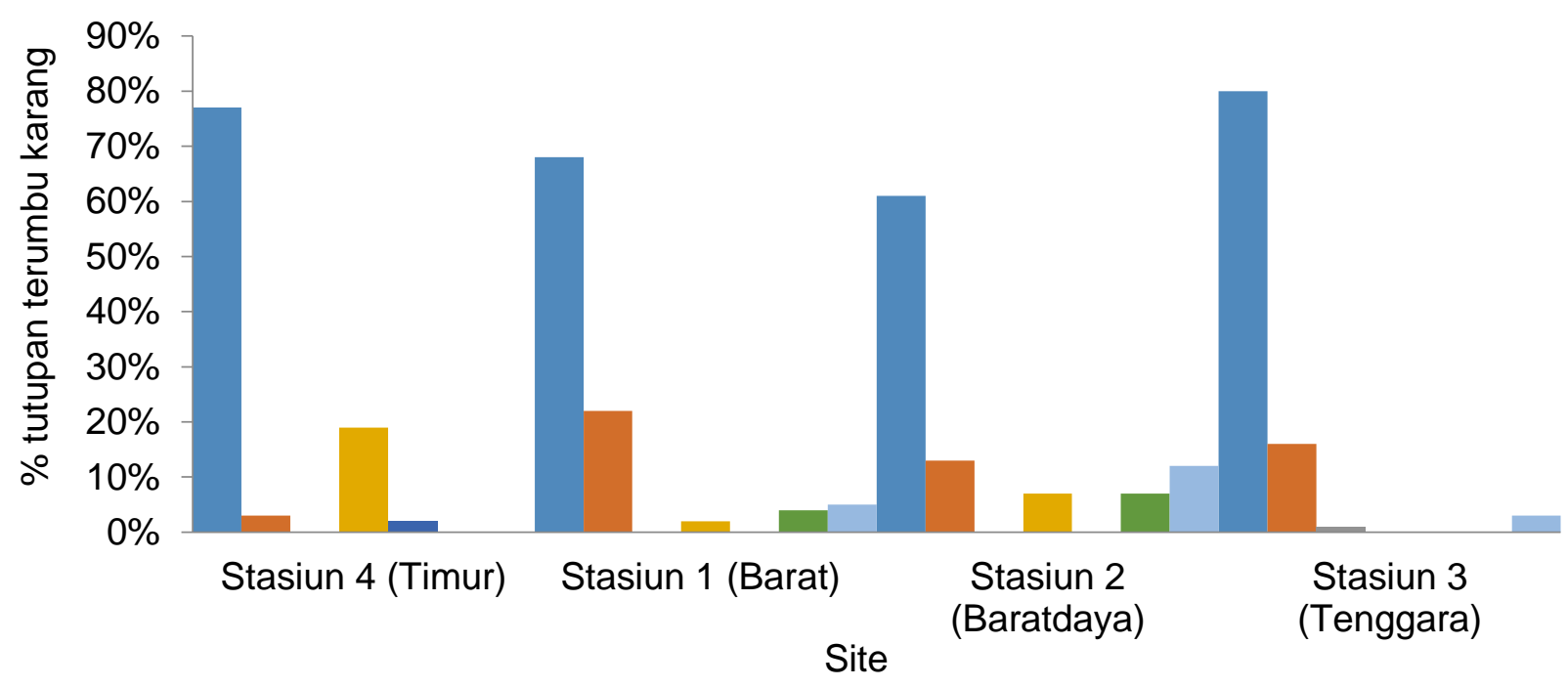

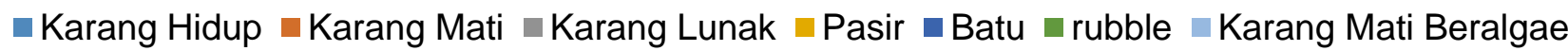

Gambar 3. Prosentase Tutupan Terumbu karang Pulau Sintok kedalaman 5 meter.

Diagram prosentase pada Gambar 3 menunjukkan perbandingan prosentase karang hidup, substrat dan komponen lainnya yang telah didata di setiap sisi perairan Pulau Sintok Karimunjawa. Dari gambar 5 terlihat bahwa Pulau Sintok pada kedalaman 5 meter masih didominasi oleh karang hidup. Prosentase penutupan karang tertinggi pada stasiun 3 dengan nilai prosentase penutupan karang sebesar $80 \%$. Pada stasiun 4 kedalaman 5 meter didominasi karang hidup dengan prosentase $77 \%$ dan substrat yang didapat pada stasiun 4 didominasi oleh pasir dengan prosentase $19 \%$. Pada stasiun 1 memiliki tutupan karang hidup sebesar $68 \%$, sedangkan pada sisi stasiun 2 Sintok memiliki prosentase karang hidup sebesar $61 \%$.

Dari gambar 4, terlihat bahwa prosentase penutupan karang hidup tertinggi di Pulau Sintok pada kedalaman 10 meter adalah di stasiun 4. Di stasiun 1 pada kedalaman 10 meter memiliki prosentase penutupan karang sebesar $59 \%$. Sisi stasiun 2 pada kedalaman 10 meter memiliki tutupan karang hidup paling sedikit dengan prosentase sebesar $30 \%$, Sedangkan pada stasiun 3 kedalaman 10 meter memiliki prosentase penutupan karang hidup sebesar $42 \%$. 


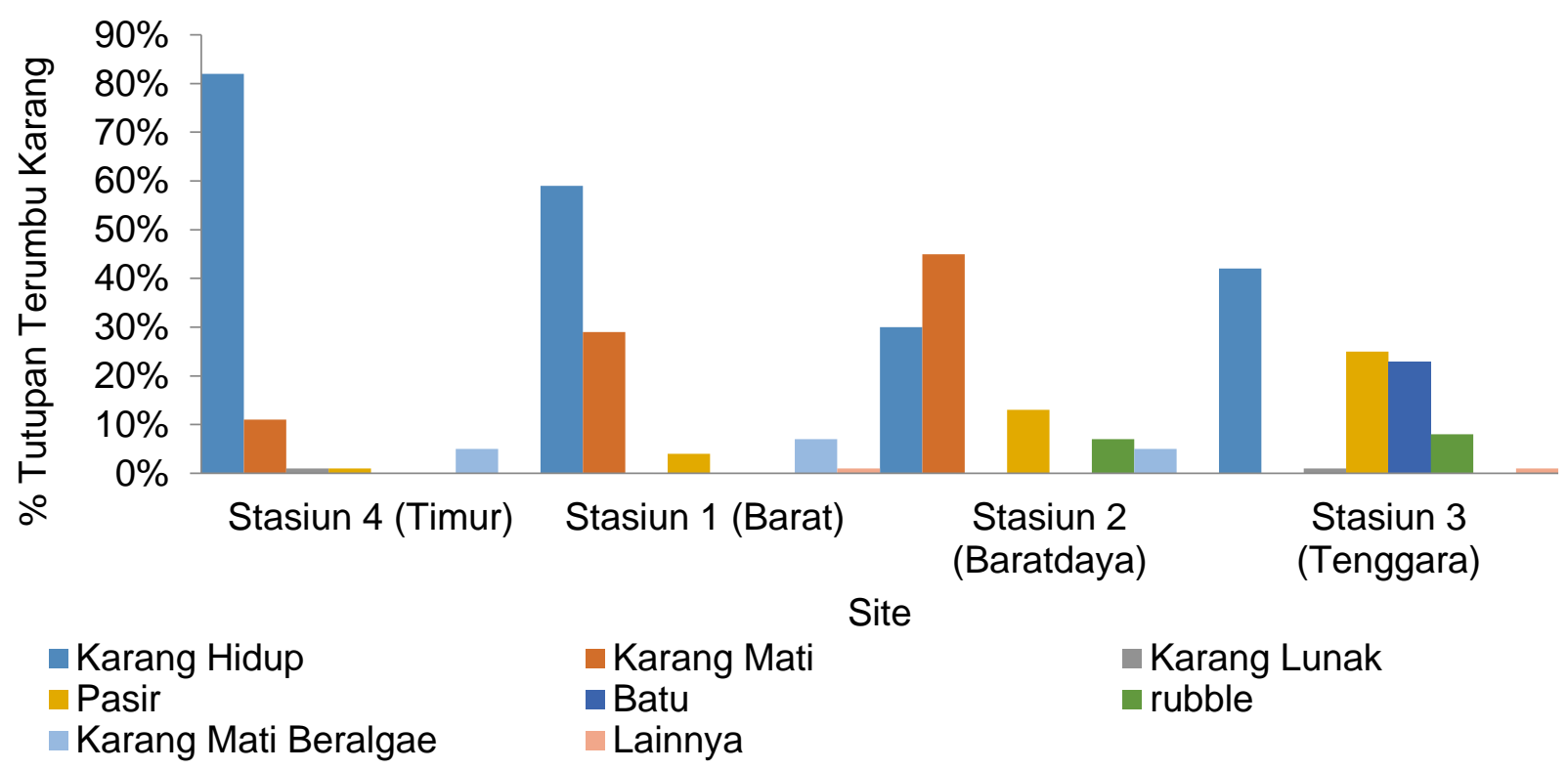

Gambar 4.Prosentase Tutupan Terumbu karang Pulau Sintok Kedalaman 10m

Tabel 4. Kemunculan Life form Disetiap Setasiun Perairan Pulau Sintok Karimunjawa

\begin{tabular}{lccccccccc}
\hline \multirow{2}{*}{ Life form } & \multicolumn{2}{c}{ Stasiun 4} & \multicolumn{2}{c}{ Stasiun 1 } & \multicolumn{2}{c}{ Stasiun 2 } & \multicolumn{2}{c}{ Stasiun 3 } \\
\cline { 2 - 8 } & $5 \mathrm{~m}$ & $10 \mathrm{~m}$ & $5 \mathrm{~m}$ & $10 \mathrm{~m}$ & $5 \mathrm{~m}$ & $10 \mathrm{~m}$ & $5 \mathrm{~m}$ & $10 \mathrm{~m}$ \\
\hline Coral massive & + & + & + & + & + & + & + & + \\
Coral Submassive & + & + & + & + & + & + & + & + \\
Coral branching & + & + & + & + & + & + & + & + \\
Acropora digitate & + & + & - & + & - & - & + & - \\
Acropora branching & + & + & + & + & - & - & - & + \\
Acropora tabulate & + & + & + & - & + & - & - & + \\
Coral foliose & + & + & + & + & + & + & + & + \\
Coral encrusting & + & + & + & + & + & + & + & - \\
Coral mushroom & + & + & + & - & + & + & - & - \\
Dead coral & + & + & + & + & + & + & + & + \\
Dead coral algae & - & + & + & + & + & + & + & - \\
Sand & + & + & + & + & + & + & - & + \\
Rubble & - & + & + & + & + & + & - & + \\
Rock & + & - & - & - & - & - & - & + \\
Soft coral & + & + & - & - & - & - & + & + \\
Sponges & - & - & - & + & - & + & - & - \\
Others & - & - & - & + & - & - & - & + \\
\hline
\end{tabular}

Keterangan : (+) Terdapatnya Kehadiran life form; (-) Tidak terdapatnya kehadiran life form

Tabel 4. Menunjukan bahwa kemunculan bentuk pertumbuhan karang di setiap stasiun penelitian. Coral massive, coral submassive, coral foliose, dan coral branching adalah bentuk pertumbuhan karang yang dapat dijumpai di setiap stasiun. Sedangkan Indeks keanekaragaman $\left(H^{\prime}\right)$ pada setiap stasiun di pulau sintok memiliki nilai berkisar 0,21-0,28 dimana menurut Krebs (1985), besar indeks keanekaragaman tersebut menunjukkan keanekaragaman di titik pengambilan data tersebut dalam kategori rendah. Nilai keseragaman $(E)$ di setiap sisi pulau sintok memiliki nilai berkisar antara 0,21 sampai dengan 0,58. Nilai keseragaman terendah terdapat pada sisi baratdaya kedalaman 10 meter yang termasuk kedalam kategori tertekan, sedangkan pada sisi tenggara kedalaman 5 meter memiliki nilai keseragaman tertinggi yaitu 0,58 yang termasuk kedaalam kategori 
labil. Nilai dominansi $(C)$ pada setiap sisi pulau Sintok memiliki nilai berkisar antara 0,13-0,26 dimana menurut Odum (1993), nilai tersebut menunjukkan bahwa pada daerah tersebut tidak terjadinya dominansi.

Tabel 5. Indeks Ekologi Karang Pulau sintok Karimunjawa

\begin{tabular}{ccccc}
\hline Lokasi & Kedalaman & $\mathrm{H}^{\prime}$ (Keanekaragaman) & $\begin{array}{c}\mathrm{E} \\
\text { (Keseragaman) }\end{array}$ & $\begin{array}{c}\mathrm{C} \\
\text { (Dominansi) }\end{array}$ \\
\hline \multirow{2}{*}{ Stasiun 4 (Timur) } & $5 \mathrm{~m}$ & 0,23 & 0,23 & 0,14 \\
& $10 \mathrm{~m}$ & 0,22 & 0,22 & 0,13 \\
Stasiun1 (Barat) & $5 \mathrm{~m}$ & 0,25 & 0,25 & 0,14 \\
& $10 \mathrm{~m}$ & 0,22 & 0,22 & 0,16 \\
Stasiun 2 & $5 \mathrm{~m}$ & 0,26 & 0,36 & 0,26 \\
(Baratdaya) & $10 \mathrm{~m}$ & 0,21 & 0,21 & 0,20 \\
Stasiun 3 & $5 \mathrm{~m}$ & 0,28 & 0,58 & 0,21 \\
(Tenggara) & $10 \mathrm{~m}$ & 0,22 & 0,24 & 0,16 \\
\hline
\end{tabular}

Berdasarkan pendataan yang dilakukan pada stasiun 1, stasiun 2, stasiun 3, dan stasiun 4, didapatkan hasil berupa komposisi ikan terumbu serta indeks yang disajikan pada Gambar 5 \& 6 .

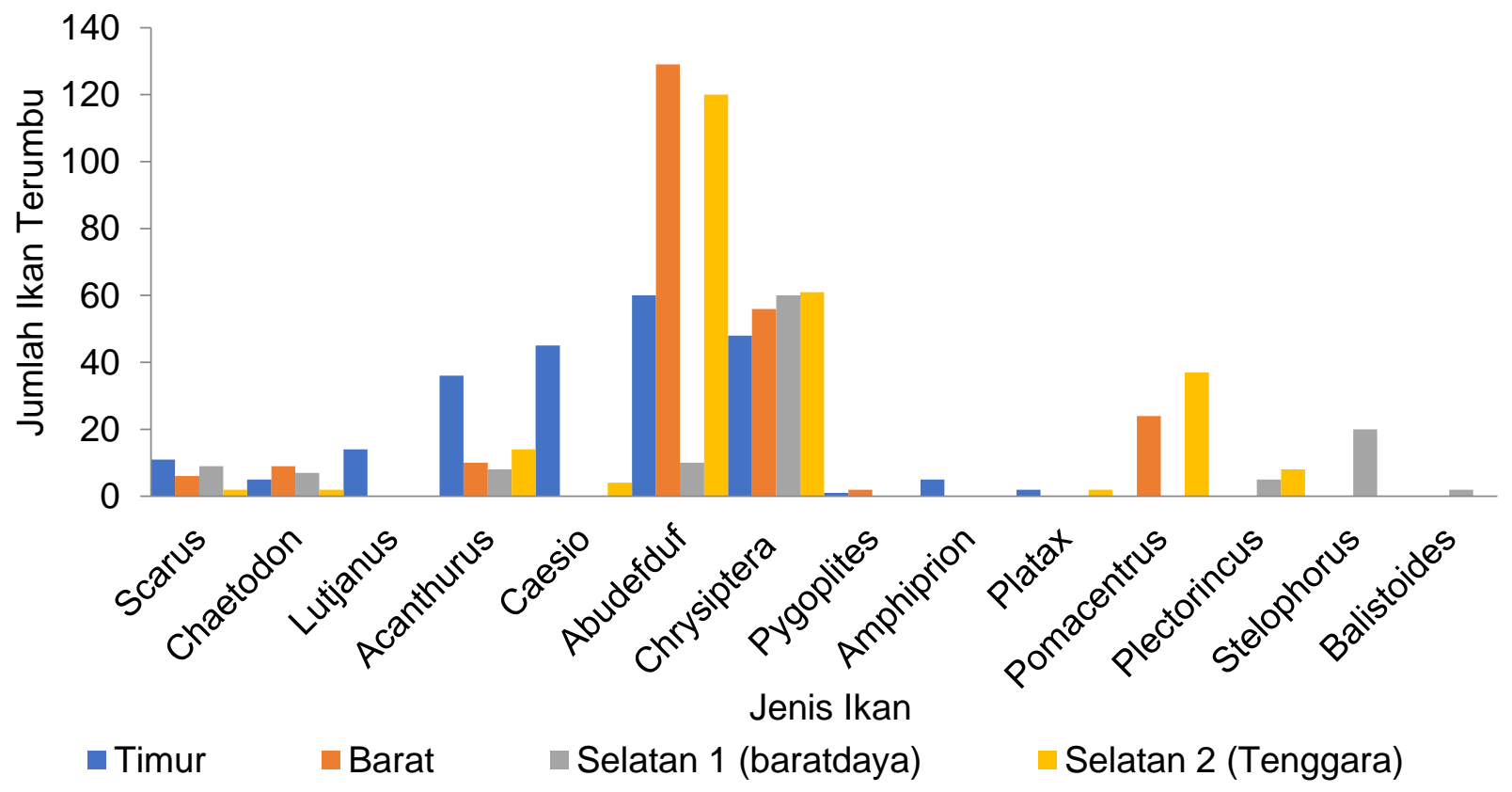

Gambar 5. Komposisi Ikan Terumbu kedalaman 5m di Pulau Sintok

Kelimpahan ikan terumbu yang tertinggi pada kedalaman 5 meter adalah genus Abudefduf dari famili Pomacentridae yaitu sebanyak 129 individu di stasiun 1, disusul pada stasiun 3 sebanyak 120 ekor dan di stasiun 4 sebanyak 60 ekor, Sedangkan pada sisi stasiun 2 ikan yang paling banyak dijumpai adalah dari genus Chrysiptera dari famili Pomacentridae dengan jumlah 60 individu. Gambar 6 menunjukkan hasil komposisi ikan terumbu di perairan Pulau Sintok pada kedalaman 10 meter. Kelimpahan ikan terumbu yang tertinggi pada kedalaman 10 meter adalah genus Abudefduf dari famili Pomacentridae yaitu sebanyak 150 individu di stasiun 2, disusul pada sisi stasiun 2 sebanyak 140 ekor dan di stasiun 4 sebanyak 90 ekor, Sedangkan pada stasiun 3 ikan yang paling banyak dijumpai adalah dari genus Stolephorus dari famili Engraulididae dengan jumlah 140 individu. 


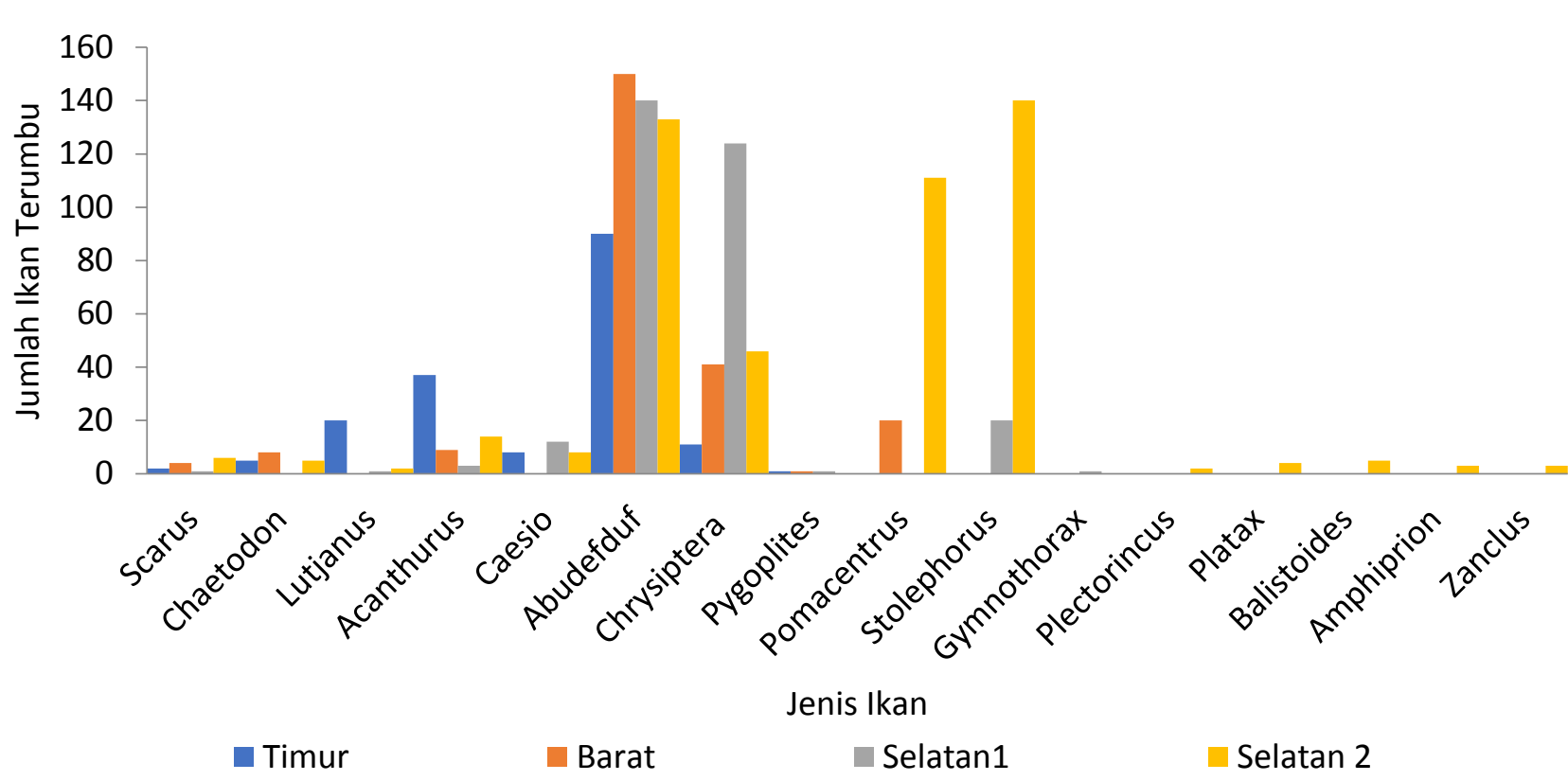

Gambar 6. Komposisi Ikan Terumbu Kedalaman 10 m di Pulau Sintok Karimunjawa

Tabel 7. Data Parameter Perairan Pulau Sintok Karimunjawa.

\begin{tabular}{cccccc}
\hline $\begin{array}{c}\text { Lokasi } \\
\text { Pendataan }\end{array}$ & $\begin{array}{c}\text { Kecepatan } \\
\text { Arus }(\mathrm{m} / \mathrm{s})\end{array}$ & Salinitas $(\% / 00)$ & $\begin{array}{c}\text { Kecerahan } \\
(\mathrm{m})\end{array}$ & Suhu $\left({ }^{\circ} \mathrm{C}\right)$ & $\mathrm{pH}$ \\
\hline $\begin{array}{c}\text { Stasiun 4 } \\
\text { (Timur) }\end{array}$ & 0,7 & 33,2 & $100 \%$ & 27,3 & 7,7 \\
$\begin{array}{c}\text { Stasiun 1 } \\
\text { (Barat) }\end{array}$ & 0,8 & 33,3 & $100 \%$ & 28,5 & 7,3 \\
$\begin{array}{c}\text { Stasiun 2 } \\
\text { (Baratdaya) }\end{array}$ & 0,1 & 34,2 & $100 \%$ & 28,3 & 7,1 \\
$\quad$ Stasiun 3 & 0,3 & 34,1 & $100 \%$ & 28,2 & 7,1 \\
(Tenggara) & & & & & \\
\hline
\end{tabular}

Faktor lingkungan yang sangat berpengaruh terhadap pertumbuhan karang adalah kualitas air atau perairan yang mencakup suhu perairan, salinitas dan kecerahan perairan. Menurut Levinton (1982), suhu adalah faktor lingkungan yang paling besar pengaruhnya terhadap pertumbuhan organisme laut seperti karang. Suharsono (1998), mengemukakan bahwa kisaran suhu yang masih dapat ditoleransi oleh karang berkisaran antara $26-34{ }^{\circ} \mathrm{C}$. Dari data yang telah di peroleh perairan Pulau Sintok mempunyai suhu dengan kisaran $27,3^{\circ} \mathrm{C}-28,5^{\circ} \mathrm{C}$, sehingga dapat disimpulkan bahwa nilai suhu terhadap pertumbuhan terumbu karang dipulau Sintok relatif stabil. Penyebab terjadinya arus diakibatkan oleh daya dorong angin, gerakan termohalin, arus pasang surut, turbulensi, tsunami dan gelombang lain. Faktor kecerahan juga mempengaruhi pertumbuhan karang karena faktor kecerahan sangat berhubungan dengan intensitas cahaya matahari. Perkembangan dan pertumbuhan karang sangat dipengaruhi oleh cahaya matahari dimana semakin cerah perairan maka semakin baik pula cahaya matahari yang diserap oleh perairan tersebut sehingga karang dapat memanfaatkannya dengan lebih optimal. Kecerahan perairan merupakan hal yang penting dalam melakukan kegiatan penyelaman, hal ini menyangkut visibility atau jarak pandang. Semakin baik jarak pandang maka keindahan bawah air juga akan semakin nyaman untuk dinikmati dengan mata dan kamera underwater (pemotretan dan video bawah laut) (Wijaya, Suryanti dan Supriharyono, 2015). Perairan Pulau Sintok memiliki kecerahan yang baik, karena kecerahannya berkisar dari 5 - 10 meter, walaupun belum memiliki kecerahan 100\%. Cahaya yang cukup harus tersedia agar fotosistesis oleh zooxanthellae simbiotik dalam jaringan karang dapat terlaksana (Nybakken, 1992). Faktor salinitas juga mempengaruhi kondisi status terumbu karang, di pererairan Pulau Sintok mempunyai range salinitas 33,2 - 34,2\%o, pada kisaran nilai salinitas tersebut terumbu 
karang dapat berkembang baik. Menurut Dahuri (2003) banyak spesies karang peka terhadap perubahan salinitas, karang hidup pada salinitas 30-35\%.

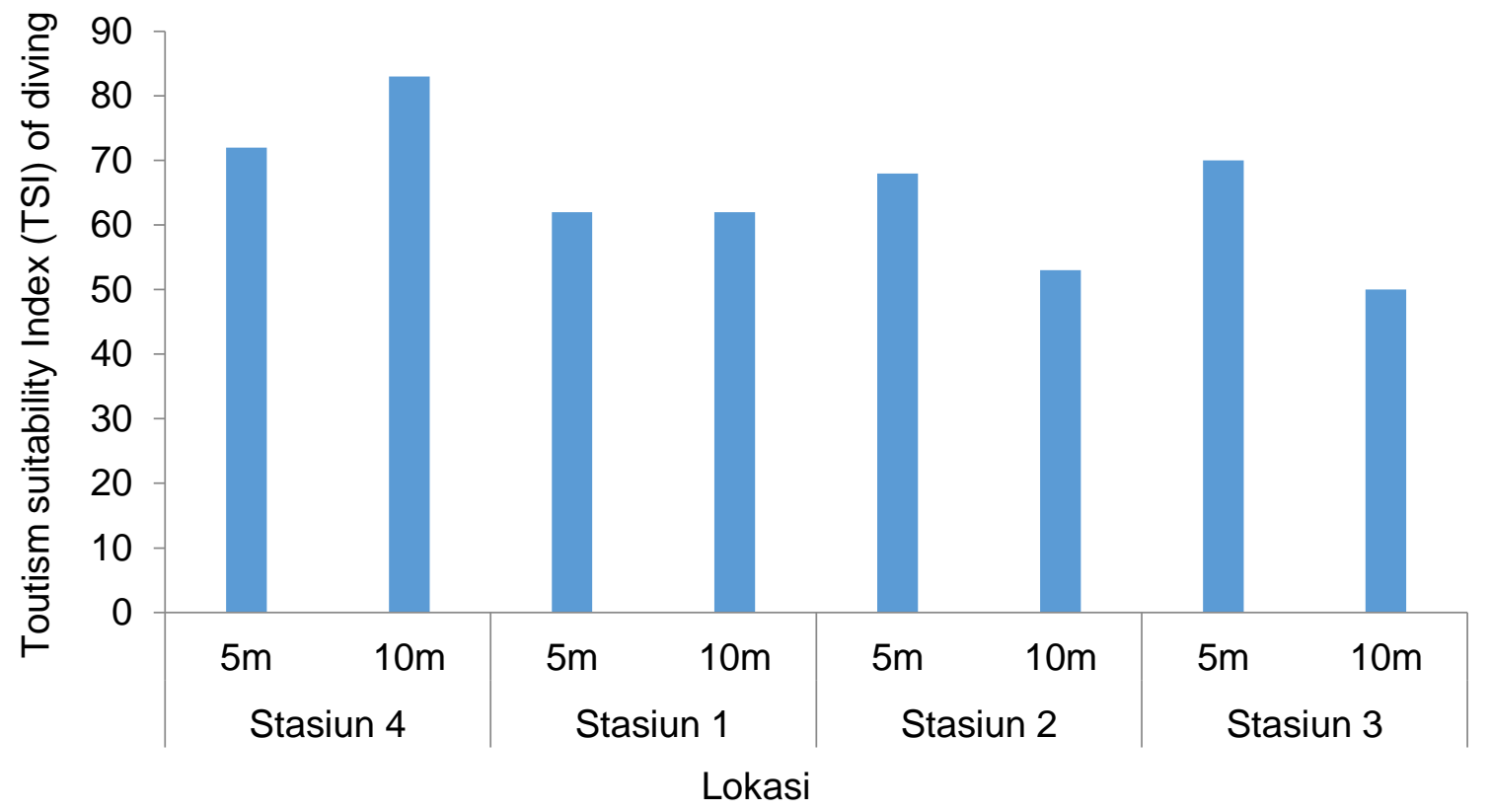

Gambar 7. Grafik analisis Indeks Kesesuaian Wisata Bahari Kategori Selam.

Pulau Sintok memiliki potensi akan dikembangkannya ekowisata terumbu karang kategori selam dilihat dari nilai IKW (Indeks Kesesuaian Selam) di keempat sisi pulau sintok. Nilai IKW tertinggi berada pada stasiun 4 kedalaman 10m Pulau Sintok yaitu 83\% yang dapat dikategorikan sebagai (S1) atau sangat sesuai (highly suitable). Menurut Yulianda (2007), kelas (S1) sangat sesuai untuk diadakannya pengembangan ekowisata terumbu karang kategori selam dimana kawasan ekosistem terumbu karang tidak memiliki pembatas yang berat untuk dikembangkan sebagai kawasan ekowisata atau memiliki faktor pembatas yang kurang berarti dikawasan tersebut. Stasiun 4 memiliki nilai IKW yang tinggi karena didukung oleh ekosistem terumbu karang yang baik dimana memiliki tutupan karang hidup sebesar $82 \%$, kecerahan perairan yang baik, dan jumlah life form karang yang beragam.

Pulau Sintok stasiun $4(5 \mathrm{~m})$, stasiun 1, stasiun 2, dan stasiun 3 termasuk kedalam kelas S2 (suitable) yang memiliki nilai IKW $50 \%-<72 \%$. Kelas 2 yaitu sesuai (suitable) sebagai lokasi pengembangan ekowisata terumbu karang kategori selam akan tetapi masih adanya faktor pembatas untuk pemanfaatannya (Yulianda, 2007). Faktor pembatas yang dimaksud adalah diperlukan adanya upaya tindakan tertentu dalam membatasi pemanfaatan dan mengupayakan konservasi serta rehabilitasi pada lokasi tersebut. Hal tersebut dapat dikatakan Kategori kelas 2 masih dapat dikembangkan ekowisata selam akan tetapi masih mempertimbangkan aspek konservasinya.

Secara umum kondisi lingkungan perairan Pulau Sintok masih dalam kondisi baik, begitu juga dengan jumlah ikan karang dan tutupan serta life form terumbu karang masih mempunyai potensi yang baik untuk dikembangkan sebagai kawasan ekowisata karena fackor-faktor tersebut sangat penting untuk dapat memberikan kepuasan bagi wisatawan. Perairan Pulau Sintok dan sekitarnya memiliki bentuk terumbu karang yang beragam/heterogen, ini berarti bahwa lokasi tersebut mampu memberikan pengalaman dan sensasi tersendiri bagi wisatawan yang melakukan penyelaman. Selain itu Pulau Sintok memiliki kondisi topografi laut yaitu slope atau menyerupai jurang.

Pengembanyan lokasi ekowisata terumbu karang kategori selam dapat dilakukan pada kedalaman 10 meter, karena pada kedalaman ini penyelam dapat menikmati keindahan yang ada pada ekosistem terumbu karang dengan sedikit gangguan. Berbeda jika menyelam pada kedalaman rendah, penyelam akan tidak nyaman karena pengaruh arus dan ombak yang kemungkinan besar, 
begitu juga pada kedalaman lebih tinggi, disamping keanekaragaman terumbu karang dan ikan karang kecil, juga semakin rendahnya tingkat kecerahan perairan sehingga visibilitasnya rendah. Tingkat spesialisasi penyelam merupakan faktor kunci untuk pengelolaan pariwisata menyelam. Hal yang perlu diperhatikan adalah kerentanan dari bentuk percabangan (life form) pada lokasi ekosistem terumbu karang yang akan dijadikan lokasi ekowisata selam. Hal ini dikarenakan masingmasing life form memiliki daya tahan yang berbeda terhadap kerusakan yang disebabkan oleh aktivitas selam dibandingkan bentuk pertumbuhan karang lainnya.

Rencana pengelolaan kawasan ekowisata di perairan Pulau Sintok dapat dilakukan pemanfaatan dan pengelolaan terumbu karang sebagai kawasan ekowisata bahari kategori selam secara optimal. Perumusan strategi menggunakan seluruh komponen dan faktor kekuatan yang dimiliki untuk memanfaatkan peluang sebesar-besarnya. Terumbu karang dapat memberikan manfaat ekonomi yang maksimal dalam jangka waktu lama bagi masyarakat yang ikut berpartisipasi dalam pengembangan wilayah ekowisata ini asalkan masyarakat juga ikut membantu pelestarian lingkungan di sekitar ekosistem terumbu karang. Apabila dieksploitasi secara berlebih, terumbu karang dan ekosistemnya akan mengalami kerusakan yang parah dalam waktu yang singkat. Perlu adanya upaya pengelolaan dengan mempertimbangkan daya dukung (carrying capacity) ekosistem terumbu karang agar pemanfaatan ekosistem terumbu karang dapat berkelanjutan kedepannya dengan cara (1) Kawasan ekowisata terumbu karang ditetapkan secara formal sesuai zonasi yang telah disesuaikan dengan karakteristik dan daya dukungnya. Kawasan yang memiliki nilai IKW (Indeks Kesesuaian Wisata) S1 atau sangat sesuai dapat dilakukan kegiatan ekowisata kategori selam. Sedangkan kawasan yang memiliki kategori S2 dengan nilai IKW dibawah $60 \%$ tetap dapat dilakukan kegiatan ekowisata kategori selam di kawasan tersebut akan tetapi dengan membatasi pemanfaatannya di bawah daya dukung kawasan tersebut, (2) Tindakan preventif atau pencegahan terhadap ekosistem terumbu karang dilakukan untuk mengurangi dampak buruk yang diakibatkan dari kegiatan selam. Memahami dan mengetahui karakteristik dari lokasi kegiatan selam diharapkan dapat meminimalisir dampak negatif yang ditimbulkan akibat aktivitas selam, (3) Mengadakan edukasi lebih lanjut tentang lingkungan bagi pemandu selam ataupun wisatawan. Pengelolaan baik juga diperlukan terhadap akses maupun pemanfaatan lokasi penyelaman yang dikoordinasikan dengan pihak terkait.

Upaya pencegahan dalam kerusakan ekosistem terumbu karang diperlukan untuk pengelolaan kawasan wisata bahari lebih lanjut. Ekosistem terumbu karang di Pulau Sintok ditemui adanya kerusakan akibat penggunaan jangkar kapal dan penggunaan alat tangkap yang tidak sesuai, maka dari itu diperlukannya upaya pencegahan seperti ; (1) Memberi edukasi kepada masyarakat, nelayan, dan wisatawan tentang pentingnya ekosistem terumbu karang serta dampak dan akibat penggunaan alat tangkap yang merusak ekosistem terumbu karang, (2) Pengendalian atas penggunaan jaring yang dapat merusak di kawasan ekosistem terumbu karang dan pembuatan sarana prasarana yang belum ada seperti pemasangan mooring bouys pada kawasan yang akan dijadikan wilayah ekowisata, karena meurut Darmono et al. (2016), penggunaan jaring yang tidak ramah lingkungan dapat merusak ekosistem sekitar, (3) Pengawasan terhadap ekosistem terumbu karang yang melibatkan instansi terkait dan masyarakat, pengawasan tidak hanya dilakukan pada perairan saja tetapi juga seluruh aktivitas yang berdampak terhadap terumbu karang.

Rencana strategi pengelolaan wilayah ekowisata di Pulau Sintok juga dapat dilakukan dengan pengembangan sistem informasi dan kelembagaan, selain itu juga meningkatkan sarana prasarananya. Pengembangan sistem informasi dapat dilakukan dengan cara (1) Penyediaan informasi tentang potensi kawasan selam berdasarkan karakteristik sumberdaya, (2) Penyediaan data daya dukung tingkat pemanfaatan terumbu karang untuk kegiatan ekowisata selam, (3) Penyediaan informasi tentang keselamatan wisatawan seperti pola arus, musim, dan SOP. Dalam penerapan pengelolaan ekosistem terumbu karang secara lestari dan secara berkelanjutan sangat diperlukan elemen hukum dan peraturan perundang-undangan yang sesuai. Sangsi hukum untuk perusak ekosistem terumbu karang dan sumberdaya perikanan selama ini kurang sesuai dengan perbuatan yang telah diperbuat, maka dari itu perlu adanya sangsi tegas dari pemerintah daerah serta instansi terkait.

\section{KESIMPULAN}


Berdasarkan Kondisi terumbu karang, ikan karang dan kondisi perairan pada Pulau Sintok, khususnya lokasi penelitian dapat dikembangkan sebagai ekowisata lamun. Hal ini berdasarkan analisis kesesuaian ekowisata yang memiliki nilai IKW (Indeks Kesesuaian Wisata) $>50-83 \%$ dimana nilai $50 \%$ - < 80\% termasuk kedalam kelas (S2) atau suitable dan nilai IKW $83 \%$ termasuk kedalam kategori (S1) atau sangat sesuai untuk dijadikan sebagai ekowisata terumbu karang kategori selam. Arahan strategi pengelolaan kawasan pengembangan ekowisata di perairan Pulau Sintok adalah dengan : (1) Pengelolaan kawasan terumbu karang sebagai ekowisata secara optimal, (2) Perlunya upaya pencegahan kerusakan ekosistem terumbu karang untuk dijadikan kawasan ekowisata, (3) Pengembangan sistem informasi serta meningkatkan sarana prasarana pengelolaan ekowisata, dan (4) Penegakkan hukum dan peraturan perundang-undangan demi penerapan pengelolaan terumbu karang secara lestari

\section{DAFTAR PUSTAKA}

Darmono, O.P., Sondita, M.F. \& Martasuganda, S. 2016. Teknologi Penangkapan Baronang Ramah Lingkungan di Kepulauan Seribu. Bogor. Jurnal Teknologi Perikanan dan Kelautan. 7(1):47-54.

Dahuri, R. 2003. Keanekaragaman Hayati Laut, Aset Pembangunan Berkelanjutan.

Effendi, H. 2003. Telaah Kualitas Air Bagi Pengelolaan Sumber Daya dan Lingkungan Perairan. Yogyakarta : Kanisius

Gomez, E.D. \& Yap, H.T. 1988. Monitoring Reef Condition in Kenching, R. and B. E. T. Hudson(ed.): Coral Reef Management Hand Book. UNESC. Regional Office for Science and Technology for South East Asia. Jakarta.

Jaelani. 2012. Konsep Pengembangan Minasata Pulau-Pulau Kecil. Direktorat Jenderal Pesisir dan Pulau-Pulau Kecil. Direktorat Pendayagunaan Pulau-Pulau Kecil. Kementerian Kelautan dan Perikanan Indonesia. Jakarta.

[KLH RI] Kementerian Lingkungan Hidup Republik Indonesia. 2004. Baku Mutu Air Laut untuk Wisata Bahari dan Biota Laut. KLH RI.

Krebs, C. J. 1985. The Experimental Analysis of Distributionand Abundance Third edition. Harper and Row Publishers. New York

Levinton, J.S. 1982. Marine Ecology. Printice-Hall inc.

Nybakken, J.W. 1992. Biologi Laut Suatu Pendekatan Biologis. PT Gramedia. Jakarta

Odum, E.P. 1993. Dasar-Dasar Ekologi. Gajahmada University Press. Yogyakarta

Puspitasari, A.T.T., Amron, A. \& Alisyahbana, S., 2016. Struktur Komunitas Karang Berdasarkan Karakteristik Perairan di Taman Wisata Perairan (TWP) Kepulauan Anambas. Omni-Akuatika, 12(1):55-72

Rangkuti, F. 1997. Analisis SWOT: Teknik Membedah Kasus Bisnis-Reorientasi Konsep Perencanaan Strategis untuk Menghadapi Abad 21. Cetakan Ke-10. Jakarta: Gramedia Pustaka Umum

Republik Indonesia. (2007). Undang Undang Republik Indonesia Nomor 27 Tahun 2007 Tentang Pengelolaan Wilayah Pesisir Dan Pulau Pulau Kecil.

Suharsono, 2008. Jenis-Jenis Karang Di Indonesia. LIPI. Jakarta

Wijaya, N D., Suryanti, dan Supriharyono. 2015. Kesesuaian Ekosistem Terumbu Karang Untuk Kegiatan Wisata Bahari Kategori Selam Di Pulau Kayu Angin Genteng, Kepulauan Seribu. Management of Aquatic Resources. 4(4):109-118

Yulianda, F. 2007. Ekowisata Bahari Sebagai Alternatif Pemanfaatan Sumberdaya Pesisir Berbasis Konservasi. Seminar Sains Departemen Manejemen Sumberdaya Perairan. Fakultas Perikanan Dan IImu Kelautan. IPB Bogor. 